\title{
Article
}

\section{Philoxenia offered to tourists? A rural tourism perspective}

Christou, Prokopis and Sharpley, Richard Anthony john

Available at http://clok.uclan.ac.uk/24894/

Christou, Prokopis and Sharpley, Richard Anthony john ORCID: 0000-00022135-3206 (2019) Philoxenia offered to tourists? A rural tourism perspective. Tourism Management, 72 . pp. 39-51. ISSN 0261-5177

It is advisable to refer to the publisher's version if you intend to cite from the work. http://dx.doi.org/10.1016/j.tourman.2018.11.007

For more information about UCLan's research in this area go to http://www.uclan.ac.uk/researchgroups/ and search for < name of research Group>.

For information about Research generally at UCLan please go to http://www.uclan.ac.uk/research/

All outputs in CLoK are protected by Intellectual Property Rights law, including Copyright law. Copyright, IPR and Moral Rights for the works on this site are retained by the individual authors and/or other copyright owners. Terms and conditions for use of this material are defined in the policies page.

\section{CLoK}

Central Lancashire online Knowledge www.clok.uclan.ac.uk

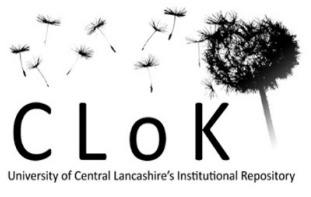




\title{
Philoxenia offered to tourists? A rural tourism perspective
}

Prokopis Christou

prokopis.christou@cut.ac.cy

Richard Sharpley

rajsharpley@uclan.ac.uk

\begin{abstract}
Tourists' perceptions of genuine hospitality may be molded by hosts' readiness and capacity to offer 'philoxenia'. This study sought to explore whether the most generous and benevolent form of hospitality, 'philoxenia', is currently attainable. Rural tourism is a fitting context because it allows generosity and strong emotional dealings between guests and hosts. Findings derived from informal interviews with stakeholders in rural tourism enterprises in Cyprus show that the notion of philoxenia is essentially founded on 'philallilia' (love for the other). However, it is called on to address challenges such as shifting societal values and a 'fear of the stranger'. Nonetheless, philoxenia can be cultivated, provided that organizational values shift towards anthropocentric rather than ego/commercial-centric activities. This paper discusses managerial implications and establishes a future research agenda for this under-researched notion.
\end{abstract}

Keywords: philoxenia, hospitality, tourist experience, rural tourism, Cyprus 


\section{Introduction}

From a social perspective, tourism is primarily defined by the nature of peoples' interactions. Hence, attempts have long been made to understand and explore the relationship between host and guest (Griffiths \& Sharpley, 2012; Tussyadiah \& Park, 2018) which lies at the heart of both tourism and hospitality (Cetin \& Okumus, 2018; Germann Molz \& Gibson, 2007). In particular, Tucker and Lynch (2005) highlight the central role that host-guest interaction plays in the guest experience, whilst the concept of hospitality more generally has also been addressed from a social perspective with the research providing us with interesting insights regarding its place and importance within societies (e.g. Höckert, 2018; Lynch et al., 2011; Poulston, 2015; Sweeney et al., 2018). Nevertheless, researchers have long recognized and continue to draw attention to the failure to develop an adequate understanding of hospitality, or suggest further research that reflects more deeply on its essential nature (Brotherton, 1999; Hemmington, 2007; Lynch, 2017; O’Connor, 2005; O’Gorman, 2007; Tasci \& Semrad, 2016). More specifically, the vast majority of publications on hospitality continue to emerge from the business sector, leading to a 'narrow focus' that reduces hospitality to an economic activity (Lynch et al., 2011, p.4).

The origins of hospitality can be traced back through the millennia to what has been referred to as 'philoxenia' (Homer's Iliad, 2004), a term that implies that a visitor is perceived and treated as a 'philos' (friend) rather than a guest. Indeed, the concept extends beyond the boundaries of commercialized hospitality; that is, it embraces the active pursuit of comforting guests, based on the principles of 'agape' or unconditional love (see Christou, 2018). Thus, philoxenia may be aligned with what can be thought of as the most generous and benevolent form of hospitality, that of 'altruistic' hospitality (Lashley, 2017, p.5). At the same time, however, philoxenia is often also underpinned by non-secular motives, particularly the provision of psychological comfort and spiritual guidance, such as by 'elders' (implying spiritually-mature people, as discussed below). A question that inevitably arises is, then: to what extent does philoxenia continue to be offered given that contemporary hospitality tends to be characterized by commercialization, automation (Lashley, 2008; Ritzer, 2017) and egocentric tendencies (Christou, 2018)? Putting it another way, destinations that experience high levels of visitation may not, according to Cetin and Okumus (2018), demonstrate the same degree of hospitableness as smaller, more 'intimate' destinations, while Brotherton and Wood (2008) suggest that the nature of hospitality has varied over time and continues to do so in different contemporary environments. Yet, it remains unclear as to what extent contemporary service providers are able or, indeed, willing to provide generous or 'altrusitic' hospitality, 
given that commercial imperatives that may interfere in this process. Hence, the purpose of this paper is to address this question. More specifically, it seeks to explore whether and to what extent philoxenia is offered today in the particular context of rural tourism, a form of tourism that demonstrates a rather idiosyncratic character in as much as its commercial governance, like that of any business activity, may be diluted by close guest-host relationships. Indeed, rural tourism has been long recognized for its characteristic yet singular host-guest relationships and also by the hospitality dynamics that it constantly promotes (Sharpley, 2002; Smith, 2009).

The present study draws on research amongst hospitality providers within the rural tourism context in Cyprus, a country that maintains a long-tradition of rural tourism provision. Extant research in Cyprus has revealed that countryside visitors are recipients of philoxenic experiences, which in turn suggests that such (rural) places - and the venues and hosts engaged in rural tourism in Cyprus - offer philoxenia (Christou, 2018; Christou et al., 2009). Nevertheless, it may be reasoned that tourists' understanding of hospitality is shaped by what hosts offer in the guise of philoxenia and, thus, it is equally important to develop an understanding of how hosts perceive hospitality in the offer-consumption process. Indeed, Sharpley (2014) argues that whilst the role of the tourist in the host-guest relationship has benefitted from extensive analysis, the same cannot be said for that of the host. More specifically, the tourism experience is based on an instantaneous production-consumption structure (Sharpley \& Stone, 2014) and, hence, it is necessary to consider providers' perspectives in the process of offering hospitality to their guests. Likewise, Cooper and Hall (2016) posit that both supply and demand are intimate components in the production and consumption of experiences by tourists and, therefore, providers clearly play a vital role in shaping guests' experiences.

In drawing conclusions from this study, which delves into the core nature of hospitality, it is hoped that a deeper understanding of the concept of hospitality will emerge. This, in turn, may equip practitioners with the knowledge they need to establish some of its principles - if indeed they are aiming to provide a holistic hospitality experience to their guests. Certainly, according to Severt et al. (2008), understanding hospitality and its provision is necessary for the overall enhancement of the tourist experience. In the following sections, the concept of philoxenia is reviewed primarily from a psycho-social perspective, though without neglecting commercial influences; in particular, philoxenia is explored within a psycho/spiritual-social context. This theoretical discussion then serves as a framework for the subsequent methodology section which discusses the study's methods, followed by a discussion of the 
research findings. The paper then concludes with a discussion of both theoretical and managerial implications and a proposed agenda for further research.

\section{Philoxenia within a psycho-social and spiritual experiential context}

Origins and expressions of philoxenia towards others

The verb philoxeno is defined as 'to offer friendship' (Zarkia, 1996, p. 163), while 'philoxenia' is a compound word comprised of philos (friend) and xenos, the latter initially meaning 'guest' but later acquiring the meaning of 'foreigner'. Although the literal translation of the word philoxenia is 'hospitality', this does not fully convey its full sense as it fails to encompass the fundamental element of philoxenia, namely, the generosity of the spirit (CYEU, 2012). In fact, philoxenia is often portrayed as a multifaceted concept that has a number of psychological and spiritual meanings attached to it, defined as it is as the affectionate behavior towards others, particularly guests (Paravouniotissa, 2011). More generally, the practice of welcoming, protecting and honoring visitors has a tradition almost as long as humanity itself and is observed in societies around the world (Blain \& Lashley, 2014). For example, as Cetin and Okumus (2018, p.229) note, the "Turkish translation for hospitality is "misafir-perverlik" starting with guest or traveler as "misafir" and "perver" as an umbrella term for feeding, protecting caring and growing'. Furthermore, as Brotherton (2005, p.139) observes, ‘... hospitality, as a philosophy, moral imperative, social practice or economic activity, has existed almost since time immemorial'. Indeed, evidence of philoxenic attitudes can be traced back to Biblical times, as in the proverbial story of Abraham and Sarah's philoxenia towards the three angels that visited them.

... when he saw them, he ran to meet them... Let now a little water be fetched, and wash your feet ... And I will fetch a morsel of bread, and stay ye your heart. (Genesis 18: 2, 4,5 - Abraham's Philoxenia)

In Homeric times, after the offering of philoxenia, families were connected with 'xenian links' that were inherited by their descendants. During that era, philoxenia was founded on the 'sympathy' that people exhibited towards others. Guests were empathized with since they were away from their homes, as 'xenon', or foreigners in different lands (Homer's Iliad, 2004). Subsequently, the statute of philoxenia was preserved as inalienable during Christian times. For example, Paul of Tarsus encouraged others to offer philoxenia as a gesture of their loveagape towards others (Christou, 2018). He urged people not to neglect the offering of 
'philoxenia' to strangers, not to wait to be asked for it but to pursue its offering (Irakleous, 2015; Paul, Epistle Paul towards Corinthians). Later, Great Basilios, known for his philanthropic actions, hosted poor, orphaned, sick and elderly people and likewise, Saint Samson hosted poor people and paupers free of charge. He offered generously without expecting anything in return. He valued the bother and the drudgery for the love of people; a kind of love that offers and is offered wholeheartedly without placing logic first (Orthodox Synaxaristis, 2018; Mantzarides, 2005a; Gregory the Thoelogist, 577CD). There are reported cases of guests referring to the offering of philoxenia, in which tangible elements (such as food) were accompanied by psychological and spiritual comfort. Even so, such incidences are mainly reported in cases where people came into contact with Elders, spiritually mature people who usually resided in monasteries or Skete. The words of Kolmogkorof (1998) reveal the philoxenia and overwhelming emotions that Elder Gabriel, for example, exhibited towards his guests:

... If they were cold... he sent blankets and bed covers; even his personal winter coats... Such love is true that only from his own mother someone could receive... (Kolmogkorof, 1998, p. 198)

Similarly, Isaak (2004) referred to a host who treated people with dry figs, hazelnuts and sweet delights. When he used to withdraw to the countryside he would leave the door of his little hut open for visitors.

I [Elder Paisios] have all the good intention to philoxeno... Only now in Winter, only one person can my hut host. Unfortunately, my hut does not agree with my heart. (Isaak, 2004, p. 208)

\section{Psychological and spiritual dimensions of Philoxenia}

As mentioned above, the offering of philoxenia is not restricted to the provision of shelter or consumable items, but also involves meeting peoples' psychological needs. It also appears to entail the offering of unconditional love, support and psychological comfort to others or, more generally, a warm welcome to the guest, reflecting Lugosi's (2014) observation that hospitality does involve gestures of welcoming. In this regard, Lynch $(2017$, p. 178) states that "viewing hospitality as welcome as a sense is highly significant as it communicates the idea of the individual as an interpreter, recipient and sensory negotiator of welcome'. Farasiotis (2005, p. 
246) stressed the love he received by people who offered philoxenia, revealing his emotional response: ‘... How comforting!... What a joy! ...'. Moreover, Elder Gabriel, in his endeavor to (psychologically) comfort a person who had lost his mother, sent a letter concluding with: 'If it is hard for you to bear it, and if you can, come to me. I hope that here, you will feel motherly love...' (Kolmogkorof, 1998, p. 198). Yet, despite the unconditional love being exhibited by hosts, philoxenia also appears to be accompanied by an empathetic stance adopted by the hosts. For instance, a well-known person in Essex (Sofronios) was regarded by his guests as 'openminded and hearty towards everyone ... He lived his [others] pains. He participated in his agonies...' (Mantzarides 2005b, p. 194). In this case, such hosts often offer philoxenia by neglecting their personal needs (for example, free time to rest) and focusing on the needs of others. In this regard, G. Basilios stressed philallilia (love for others) over philaftia (love for oneself):

Philaftia entraps a person to his Ego.... The egocentric love of a person towards himself which philaftia is identified with, leads to antithesis towards the neighbor... Philallilia puts aside the individual interest and clashes with philaftia. And because a person finds it hard to put aside his individual interest, usually he sacrifices philallilia on the altar of philaftia. (in Mantzarides 2005a, p. 92)

Additionally, sometimes philoxenia appears to be accompanied by a spiritual element. For instance, a particular host (Isaak) received people who turned to him for advice in times of sorrow and in need, while St. Seraphim was known for his palpable love for all people and the deep spiritual discussions he had with them (Moore, 2009; Speake \& Ware, 2015). In a similar case:

He [Elder Porfirios] watered and fed me spiritually, and I was receiving with gratitude and joy... The oxymoron was happening. The close to death old man, to donate live, biological and spiritual, to the 25 years old... (Farasiotis, 2005, pp. 305-306)

\section{Philoxenia within a contemporary context}

As suggested above, sincere motives on the part of hosts and their actions based on philoxenic principles appear to contradict contemporary notions of hospitality; that is, nowadays 
hospitality generally refers to commercialized activities and motives. However, despite organizational and executive activities influencing the offering of hospitality, the concept also seems to embrace a philosophical, social and psychological element which has often been lost within a management perspective:

The irony lies in the fact that in presenting to the world an idea of 'hospitality management' there is little evident understanding of what hospitality 'is' in historical or philosophical terms and little consistency in its application in terms of the delivery of hospitality services. (Brotherton \& Wood, 2008, p.37)

In their study, Cetin and Okumus (2018) identify four general components of traditional local hospitality, these being: sociability (willing to talk, welcoming and outgoing); care (trustworthy and caring); helpfulness (attentive and the desire to assist); and generosity (open to giving and thoughtful). In contrast, Lashley (2008) proposes a three-domain model as an initial means of comprehending the concept of hospitality; illustrated as a Venn diagram, this is a useful tool for considering hospitality experiences (Gehrels, 2017; Ruiter, 2017). Within the three inter-related areas of the socio-cultural, private and commercial domains, the model emphasizes the host-guest relationship and experience as a focal point. In fact, several researchers have stressed the importance of this relationship within the hospitality realm (see, for example, Causevic \& Lynch, 2009; Hemmington, 2007). Returning to Lashley's model, the private domain covers those obligations typically learnt by individuals in their home settings required to be hospitable, although some commentators also point to the important role of an individual's personality in shaping hospitable attitudes (Dekker, 2014). The socio-cultural domain embraces the variety of obligations that different societies require of people to be hospitable. In this context, reference is often made to the forms of hospitality exhibited by different cultures, or hospitality that is shaped by norms and long-honoured traditions in different societies, such as the case of Irish hospitality (Suleri, 2017). Alternatively, within the African foraging culture, hospitality manifests itself in social life through activities such as welcome dances, rituals, and gatherings (Ruiter, 2017). At the same time, the role of the family may be considered an equally important socio-cultural influence; as Lynch (2000, p. 104) notes, 'the family also has a key role to play in setting the norms of behaviour which impact upon the guest while staying in the home'. In contrast, the commercial domain is concerned with the industrialization of hospitality. In simple terms, Slattery (2002) argues that restaurant 
and hotel services involve a management activity and, from this perspective, the transaction between the host and the guest is essentially an economic one.

In a similar vein, in a review of studies on hospitality, Lashley $(2017$, p.4) identifies a number of motives amongst hosts offering hospitality to guests which he maps on a continuum ranging from those calculative reasons for providing hospitality to the more generous motives. Essentially, at one end lie 'ulterior motives' and 'commercial' hospitality while 'redistributive' and 'altruistic' hospitality (that is, genuine motives) lie at the opposite end. For instance, Suleri (2017) refers to an incidence of 'ulterior motives' hospitality: 'After a long journey, I encountered the rudest ever behavior from an immigration officer ...' (p. 329). Conversely, altruistic hospitality is considered to be the sincerest form of hospitality, characterizations of it including genuine (Telfer, 2013), radical (Derrida, 2002), unconditional (Suleri, 2017) and, ultimately, generosity (Blain \& Lashley, 2014). And as already noted, it is this form of hospitality that most closely reflects the principles of philoxenia (Christou, 2017).

Nonetheless, this does not imply that sincere forms of hospitality and support for guests are not expressed within a commercialized environment. For example, Rosenbaum (2009) found that indirect service employees emerge as key providers of social support, despite the fact that they do not directly receive tips from customers. Although it could be argued that 'true' philoxenia can only offered exclusively by Elders - who may be driven by philalillia rather than commercial motives - philoxenia nevertheless appears to be linked particularly with tourism venues and other small establishments in rural areas. In such cases, the domestic and commercial aspects of hospitality and hospitableness are most likely to overlap (Lashley, 2015a). In other words, it is more likely to occur within a particular (that is, rural) environment which is generally recognized for offering emotional experiences to its visitors, such as in the case of the British countryside (Sharpley \& Jepson, 2011).

On the same note, Cyprus has long sought to develop a unique rural tourism product founded on the notion of 'philoxenia' (Sharpley, 2002, p. 237). Whether reflecting the actual practices of rural tourism providers or understood as a form of simple and crude marketing, the trope 'experience our hospitality' (or similar) is used by rural tourist establishments as means of encouraging tourist visitation, not only in Cyprus but also elsewhere. For example, rural tourism venues in Calabria in Italy inspire tourists to engage in a rural tourism experience by claiming that guests will benefit from genuine hospitality (The Buonvicino Rural Tourism, 2015) whilst in Cyprus, a number of organizations refer to the 'philoxenia' that rural tourists may experience (Choose your Cyprus, 2016). For example, Lyhnos (2016), a small agritourism hotel invites its guests to: 'Receive our love and our philoxenia...'. 
However, despite claims of the existence of 'altruistic' hospitality (Suleri, 2017), some challenge the argument that contemporary tourists may experience sincere hospitality, not least because, according to Lashley (2008), many industrialized societies no longer possess or exhibit a strong obligation towards offering hospitality to strangers:

Today, the guest-xenos is a tourist, who is a client. The host offers "services" and not "friendship", and the xenos-tourist pays for it. Their relationship is ruled by the laws of commerce... (Zarkia, 1996, p. 163)

Similarly, Ritzer (2017, p. 254), while referring to the automation of hospitality, questions whether what is being offered in most tourism establishments nowadays is 'true hospitality'. Therefore, it is unsurprising that additional research into the existence of altruistic hospitality is called for, particularly within the context of small establishments (Lashley, 2017; Lashley, 2015a). In contrast, others concur that hospitality extends beyond managerial activities, primarily because it is regarded as an emotionally-laden concept, a sociopsychological, human phenomenon that revolves around the guest-host relationship and is a central feature of human experience (Ruiter, 2017; Skandrani \& Kamoun, 2014; Tasci \& Semrad, 2016). Furthermore, Hemmington (2007) recommends focusing on hosts' psychological offerings (such as generosity) on the basis that they will equip guests with experiences that are personal, memorable and add value to their lives. Conceivably, the benefits of such offerings are not only restricted to private gains, but may extend at a social level. Caring for the 'xenon' could, as Irakleous (2015) stresses, empower us with significant principles for a solidarity stance and social critique.

\section{Study method and research questions}

As outlined above, the purpose of this study is to explore the extent to which rural tourism hosts seek to provide philoxenic experiences to their guests, despite claims that contemporary host-guest relationships are primarily determined by a commercial imperative (Hemmington, 2007). In particular, the study focuses on both private and public stakeholders in rural tourism enterprises in Cyprus, such as the owners of rural tourism accommodation establishments, that distinctively promote hospitality for rural tourism consumption (Lyhnos, 2016; Smith, 2009). Given the exploratory nature of the study, a qualitative approach through the use of interviews was deemed more appropriate to examine in-depth the notion of philoxenia. Such a technique permits thorough explorations of personal phenomena, hence contributing to in-depth 
understandings (Christou et al., 2018) whilst, according to Lynch (2005), explorations of hospitality transactions in particular can benefit from a readiness to employ a range of qualitative techniques.

In this study, it was anticipated that this method would encourage informants to elaborate and divulge probable philoxenic actions through the use of examples, and to reveal underlying feelings in a more personal and enlightening manner than other research methods would allow. Informal semi-structured interviews were therefore conducted on the basis that they put people at ease and make it possible to acquire information that may indicate respondents' underlying feelings (Henn et al., 2006). Interviews were conducted by an experienced researcher with participants who were selected on a purposive (Tongco, 2007) and convenience sampling basis. Purposeful sampling is widely used in qualitative research (Palinkas et al., 2015; Patton, 2014) and 'requires access to key informants in the field who can help in identifying information-rich cases" (Suri, 2011, p.66). Moreover, as Patton (2007) stresses, qualitative inquiry typically focuses in depth on relatively small samples, selected purposefully. More specifically, it was ensured that the views of a variety of operators / owners of rural tourism establishments (e.g. accommodation and restaurant owners) were represented, and that different sub-regions (and venues within them) were included in an attempt to construct a sample that represented a broad range of circumstances (Griffin, 2013).

Figure 1: The hinterland of Cyprus and the regions in which the interviews took place

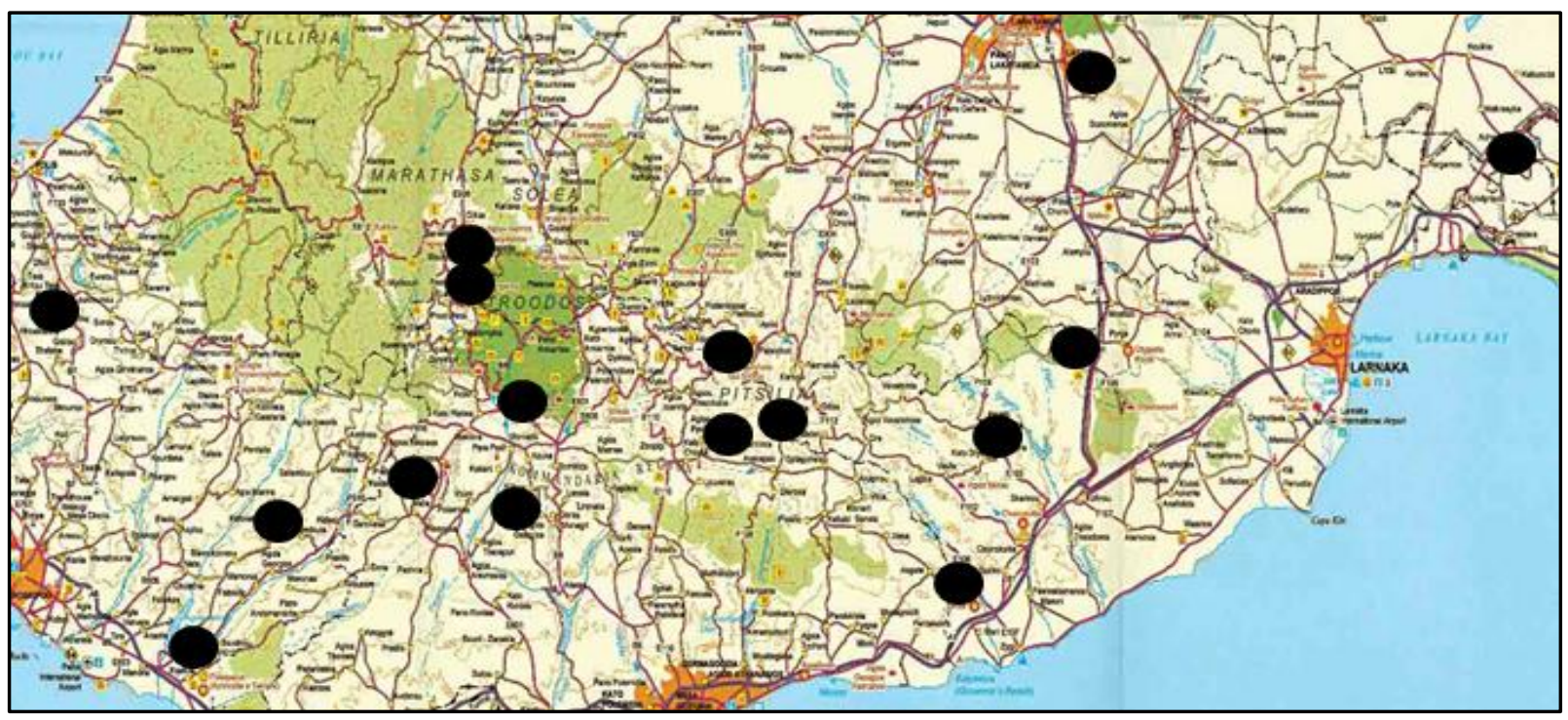

Map source: Cyprus Tourism Organization: A Visitor's map of Cyprus, 2006. 
The sample included hosts who were willing to share their thoughts and understandings on the notion of philoxenia, and whose venues are located both close to and more distant from urban areas in order to allow a holistic presentation of rural hosts' perceptions from differing settings (see Figure 1).

It should be noted that, in qualitative sampling, neither statistical representation nor even scale are key considerations (Holloway \& Jefferson, 2013). Rather, rigor is defined by the sample's ability to represent salient characteristics (Ritchie et al., 2014), in this case, the perceptions and opinions of various rural tourism stakeholders. Therefore, different rural tourism organizations were selected from official lists (for example, Cyprus Agritourism Company) and contacted via telephone. Those that agreed to participate were retained in the study and were approached in their natural setting, that is, within their venues (accommodation establishments and centers). Interviews were subsequently conducted with 23 owners and hosts of rural tourism organizations over a two-month period. Other relevant studies have followed a similar method, such as Skokic, Lynch and Morrison's (2016) qualitative research which included findings from in-depth interviews with 37 entrepreneurs. In this study, the informants included the owners/hosts of eight rural tourism-hosting (accommodation) venues, nine food and beverage enterprises (including traditional taverns and restaurants), three small rural tourism hotels, one endemic-animal theme park, the owner of a traditional workshop, and the host of a community municipality (event department) center (see Table 1: Informants' profiles).

Both the informants and the villages in which interviews were conducted were anonymized, since in some of the villages where the research took place there is only one accommodation establishment. Most interviews lasted approximately half an hour (although some longer), and were generated from a list of general questions, as in similar studies (e.g. Christou et al., 2018). The questions were open-ended, allowing informants to share their understanding of the notion of 'philoxenia' and how is practiced. Patton (2014) notes that openended questions yield more in-depth replies about people's perceptions. Questions were firstly piloted with real respondents (Brotherton, 2015, p. 190) and were adjusted accordingly, first to better meet the study's objectives, second to be clear and interesting for the respondents and third to allow sufficient opportunities to probe further into the topic. Despite this, some of the questions asked carried the risk of influencing responses. For instance, asking someone whether they believe that the offering of philoxenia has changed over the years may lead the respondent to assume that it has changed. Yet, the questions were shaped based on the aforementioned reasons. 
Table 1: Informants' profiles

\begin{tabular}{|c|c|c|c|c|c|}
\hline Informant & Pseudonym & Gender & Age & Organization & Status/Role \\
\hline 1 & Olga & $\mathrm{F}$ & 61 & $\begin{array}{l}\text { Rural tourism hosting (accommodation) } \\
\text { venue }\end{array}$ & Owner \\
\hline 2 & David & $\mathrm{M}$ & 48 & $\begin{array}{l}\text { Rural tourism hosting (accommodation) } \\
\text { venue }\end{array}$ & Owner \\
\hline 3 & Antony & $\mathrm{M}$ & 58 & $\begin{array}{l}\text { Rural tourism hosting (accommodation) } \\
\text { venue }\end{array}$ & Owner \\
\hline 4 & Fotini & $\mathrm{F}$ & 53 & $\begin{array}{l}\text { Rural tourism hosting (accommodation) } \\
\text { venue }\end{array}$ & Owner \\
\hline 5 & Chris & $\mathrm{M}$ & 62 & $\begin{array}{l}\text { Rural tourism hosting (accommodation) } \\
\text { venue }\end{array}$ & Owner \\
\hline 6 & Stephen & $\mathrm{M}$ & 53 & $\begin{array}{l}\text { Rural tourism hosting (accommodation) } \\
\text { venue }\end{array}$ & Owner \\
\hline 7 & Mary & $\mathrm{F}$ & 38 & $\begin{array}{l}\text { Rural tourism hosting (accommodation) } \\
\text { venue }\end{array}$ & Owner \\
\hline 8 & Eleni & $\mathrm{F}$ & 41 & $\begin{array}{l}\text { Rural tourism hosting (accommodation) } \\
\text { venue }\end{array}$ & Manager \\
\hline 9 & Panos & $\mathrm{M}$ & 52 & F\&B enterprise (Restaurant) & Owner \\
\hline 10 & Andreas & $\mathrm{M}$ & 48 & F\&B enterprise (Restaurant) & Owner \\
\hline 11 & Michael & $\mathrm{M}$ & 42 & F\&B enterprise (traditional tavern) & Owner \\
\hline 12 & Marios & $\mathrm{M}$ & 31 & F\&B enterprise (traditional tavern) & Owner \\
\hline 13 & Petros & $\mathrm{M}$ & 56 & F\&B enterprise (traditional tavern) & Owner \\
\hline 14 & Fani & $\mathrm{F}$ & 46 & F\&B enterprise (traditional tavern) & Manager \\
\hline 15 & Yiannis & $\mathrm{M}$ & 44 & F\&B enterprise (café) & Owner \\
\hline 16 & Chrysanthi & $\mathrm{F}$ & 38 & F\&B enterprise (café) & Owner \\
\hline 17 & Chrystalla & $\mathrm{F}$ & 28 & F\&B enterprise (café) & Owner \\
\hline 18 & Daniel & $\mathrm{M}$ & 39 & Rural tourism hotel & Owner \\
\hline 19 & Kyriakos & M & 50 & Rural tourism hotel & Manager \\
\hline 20 & Costas & $\mathrm{M}$ & 41 & Rural tourism hotel & Manager \\
\hline 21 & Christakis & M & 47 & Endemic-animal theme park & Owner \\
\hline 22 & Rodotheos & $\mathrm{M}$ & 63 & Traditional countryside workshop & Owner \\
\hline 23 & Sylvia & $\mathrm{F}$ & 33 & Community municipality & $\begin{array}{l}\text { Hostess/event } \\
\text { organizer }\end{array}$ \\
\hline
\end{tabular}

More specifically, and as previously discussed in the theoretical section, research undertaken has already established that the offering of hospitality has been subject to various transformations in recent times and, hence, it was deemed interesting to identify not if but in what ways (that is, how) it has changed. Besides, according to Cetin and Okumus (2018), understandings of and meanings attached to hospitality in general differ depending on perspectives. Moreover, the key abstract concept in this study was 'philoxenia', the aim being to encourage informants to share their understanding of it without initially defining the term to them. Conceivably this carried the risk of multiple interpretations reflecting personal 
understandings; as Lugosi (2017, p.20) notes, 'a significant problem inhibiting practitioner engagement is the use of abstract concepts'. Nevertheless, informants were left to express their views and feelings freely so that concepts emerged naturally. The guiding questions were as follows:

- What is your understanding of the term philoxenia? Do you believe that it differs from the word 'hospitality'? If so, how?

- How do you offer 'philoxenia' to your visitors? Can you provide specific examples? Do you believe that what you offer to them differs from what they are being offered elsewhere (such as a large resort)?

- Do you believe that the offering of philoxenia has changed? If so, how? What do you believe is its future?

- What factors, actions or behaviours may promote, or even impede the offering of philoxenia?

Responses from all informants were noted down verbatim, whilst other important information, such as details about the setting, was recorded for subsequent analysis. Interviews were conducted mainly in Greek (although some in English) and were then translated and transcribed by a professional in English. Each interview yielded on average 800 transcribed words although, perhaps inevitably, some informants were more willing than others to share personal experiences and examples from their daily routine (though always related to the concept of philoxenia). Having completed 23 interviews, saturation was reached. That is, newly collected information simply re-enforced that which had already been gathered (Mariampolski, 2006). Similar exploratory studies have also reached saturation after 20 interviews (Choi \& Fu, 2018).

Data analysis involved reflection, identification of themes and assessing understanding in relation to the literature (Di Domenico \& Lynch, 2007). More specifically, the analysis of the information started from the collection phase with the reading the replies of each interviewee and delving deeper into each issue (Hennink et al., 2011). The topics that emerged from the responses were then grouped into interrelated themes, which made it possible to identify thematic categories and assisted in the process of reaching conclusions. A general inductive approach (Thomas, 2006) was used to analyze information from interviews, the aim being to condense raw textual data into a summary format. Hence, specific themes were 
developed which captured core messages reported by participants; these were then grouped into broader categories which were labelled accordingly (for example, Theme A: Meanings of philoxenia; Theme B: Philoxenia throughout time). Following this, major themes developed from these specific themes were then identified and described in the findings (e.g. sub-theme of Theme A: The offering of philoxenia - what it entails; sub-themes of Theme B: How was philoxenia practiced in the past, and how it is practiced in currently). The findings of the study are now presented in the following section, supported by direct quotations from representative replies.

\section{Study findings}

The themes emerging from the 23 semi-structured interviews are presented in this section. First, how the informants perceived the concept of philoxenia is revealed; this is then followed with a discussion of whether and how they offer philoxenia to their guests.

\section{Understanding of philoxenia: The exclusivity of the concept}

While describing their understanding of 'philoxenia', informants made clear linkages between the concept and certain tangible and intangible elements of the service they offer, such elements being provided with the ultimate goal of pleasing guests without directly (as some indicated) aiming for financial compensation. Specifically, some interviewees used terms such as 'kind treatment', 'politeness' and 'helpfulness' to describe the concept; in other cases, positive physical expressions, such as a smile, and positive emotions, such as love, were also included in their replies. At the same time, interviewees used the word 'guest' more frequently than 'customer' or 'visitor', as in the following response:

Philoxenia is greeting our guests with a smile and showing love and respect to them ... It [philoxenia] means warmth, familiarity... offering to our guests a beverage or something to eat, without worrying about profit, but rather for the guests to feel comfortable... We aim not only to fulfil the needs of our guests, but also to offer more than what they expect and want, in an effort to make them feel as home... Once, I asked a guest if he wanted me to prepare something else for him, since he didn't like the food... Although he replied "no, thank you", he appreciated my readiness to provide an alternative to him. (Fotini, 53, rural accommodation owner) 
This example gives further value to the views of Tasci and Semrad (2016), who highlight the emotionally-laden dimensions of interchanges between hosts and guests. Nevertheless, informants also interpreted the concept of philoxenia as the provision of services that seek to make the guest feel comfortable or, as one interviewee put it, to experience 'unique hospitality' (Chrystalla, 28, café owner). Most of the interviewees also concurred that the actual term philoxenia differs from the term 'hospitality', despite the two frequently being used interchangeably. More specifically, they associated the word 'hospitality' with service provision and standardized procedures with a profit orientation. As discussed above, Lashley (2015b) distinguishes genuine hospitality as being unconcerned with repayment or reciprocity. Likewise, in the present study, interviewees associated philoxenia with words such as authenticity and friendliness, whilst the term was also linked to the uniqueness of the destination, with almost all informants expressing similar views to the following one:

... I find that the word hospitality is a rather 'neutral' term. It is a profitoriented term that lacks warmth. It mostly refers to the provision of a standardized service, rather than the need and feeling of getting closer to the guest. Philoxenia entails the word 'philos' [friend], which encompasses the emotion of love. Personally, I call someone that I love, that I care for, my friend... And we [implying hosts] should care for our guests... Philoxenia is more authentic and closer to our traditions, which focus on making people feel like home by creating a friendly environment without caring about profit only... It [philoxenia] is an integral part of the Cypriot culture since it is a unique element of our identity to be hospitable and warm to our guests, whether they visit our village, our hotel, tavern, shop, or even our house. (Stephen, 53, rural accommodation owner)

It is noteworthy that the majority of informants agreed that people are born to be philoxenic while, in contrast, those who are trained in aspects hospitality provision (such as politeness) might display an approach 'that is shallow' (Marios, 31, tavern owner). One respondent made reference to the gift and 'charisma of philoxenia' that someone may possess. This may be easily identifiable by the receiver, even with a simple gesture such as a 'genuine smile'. Similarly, another interviewee said that an individual may be born to be 'sociable' and eventually learn to be hospitable. Relevantly, some interviewees stressed the significance of the immediate family and the role of proper training in shaping an individual's hospitable traits. 
My personal view is that people are born philoxenic since it is a matter of character to please and even comfort others... What I mean is that in our culture it is important to be hospitable towards strangers, but you see that some people are not willing to invite you to their homes to have a coffee... Or, if they invite you, they are very cautious with their portions. They are aphiloxenic [implying non-philoxenic]... But it [philoxenia] can also be nurtured by our family since our parents might also be naturally philoxenic and they may pass this to their children ... What I mean is that a child learns from his parents to act in the same [hospitable] manner towards others... A child may see his parents taking care of their guests, so he learns to act in the same manner towards his own guests. (David, 48, rural accommodation owner)

I believe that a person is born to be philoxenic... to show kindness, to make guests feel welcome, to share with them their food without asking for a return... Even if a person is born philoxenic, he must seek proper training since this enables people to develop their skills even more. Thus, a person must not feel that he is philoxenic enough because it is in his character and because he was directed by his family to offer philoxenia. He owes it to himself to further develop as a person and equip himself with additional valuable skills. (Olga, 61, rural accommodation owner)

\section{Philoxenia within the rural tourism context}

Although not necessarily restricted to the non-secular offering, informants appeared to agree that philoxenia is most likely to be experienced by someone through intangible offerings. Nevertheless, they also acknowledged the importance of the tangible element, such as offering the guest a cold beverage on a hot summer day without requesting payment. Based on the interviewees' comments, being open to guests' views, treating them with respect, communicating with them, and showing 'empathy' are good indicators of a philoxenic attitude. However, as one interviewee noted, this requires 'hard work and setting standards and goals which will make guests feel like home' (Mary, 38, rural accommodation owner). Also, informants made specific reference to the rural setting, which they feel fosters philoxenia owing to the unique characteristics and activities of the rural tourism experience. Examples 
included locals sharing certain practices with tourists, such as baking bread together. Such activities are undertaken in an attempt to make visitors feel engaged and more comfortable within a friendly environment. Two such representative views are as follows:

... Philoxenia can be fostered easily in rural tourism since the environment is friendlier, away from the busy life of the city, which gives us [implying owners of rural tourism accommodation establishments] the opportunity to devote more time to our guests... If you have more time to devote to your guests, they will receive more attention from you. Besides, rural tourism is linked with personal communication with the guest ... the fact that most establishments are owned by families makes the atmosphere in the establishment friendlier and more welcoming for the guest ... (Mary, 38, rural accommodation owner)

We [rural tourism accommodation owners] try to communicate with our guests and together create an itinerary for them [referring to tours and excursions] that will fulfil their needs; I casually ask them questions about them and their country in order to find out more about their preferences, since guests prefer personal contact more than the provision of small amenities ... (Daniel, 39, owner of small rural tourism enterprise/hotel)

\section{Philoxenia: Past, present, and future}

Informants expressed concerns regarding the shifting values of people, the economic uncertainty (for example, the global financial crisis), fear (towards 'strangers'), and current trends within the tourism industry. They felt that all of these factors impact negatively on the offering of philoxenia. Certainly, almost all interviewees agreed that understandings of philoxenia are now different to how they were in the past.

The world has become more materialistic and rather selfish ... people in large cities have drifted away from traditions and a simpler way of life [in comparison to the past] ... certain values like philoxenia that our ancestors shared and used to have when living in the villages are no longer practiced by people nowadays... It's very hard to find someone who is genuinely philoxenic, without having in his back of his mind on how to benefit from 
you... and this is truly sad and disappointing ... (Antony, 58, rural accommodation owner)

One informant referred to the economic factor that may interfere in the process of offering philoxenia; someone may be willing to provide philoxenia but economic necessity might restrict the extent to which it is offered. Interestingly, another said that the 'fear factor' may be manifested in an unwillingness to help a stranger. According to this interviewee, this fear results from perceived increased levels and risk of crime. Some informants also referred specifically to careless handling of 'all-inclusive' packages, mass tourism and mechanical procedures/services which have contributed towards organizations and people in drifting away from philoxenic principles. In the past, the economic crisis enforced feelings of insecurity and 'disappointment"' amongst tourism stakeholders, resulting in them 'caring more about surviving and making a profit, rather than exhibiting philoxenia' (Antony, 58, rural accommodation owner). The view was also expressed that tourists themselves have changed; according to some interviewees, hosts are unwilling to offer philoxenia to tourists who actually demand it:

Tourists have changed... At least this is what I believe. I've had this venue [referring to rural accommodation establishment] for many years. I've hosted many people, not only from Cyprus, but from around the world... from Germany, France, even Australia ... Some of them return ... But in general, I find that my guests have changed ... Maybe I changed ... who knows... [laughing]... They [referring to hosting tourists] are more demanding and wish that things be done in a certain way; their way ... They don't like this, they don't like the other thing ... It's very hard to please someone who 'demands' your service, your attention and your hospitality ... People have become selfish ... (Chris, 62, rural accommodation owner)

Despite such concerns, the research generally revealed a more sanguine and promising view specifically directed towards the rural tourism sector, although responses by informants betrayed a disappointing view that philoxenia has altered and 'deteriorated' over the years. Despite this, an overall positive feeling emerged from the interviews that that philoxenia has and will continue - to benefit rural tourism in particular, with tourists seeking a 'philoxenic experience", 
People feel nostalgic of a simpler way of life ... Especially if they grew up in a place in which things were simpler without many distractions, noise and stress ... People in general want to escape from their busy everyday lives; they visit the countryside, which is quieter, they mingle with the locals and stay in rural tourism establishments. Even the locals [referring to domestic tourists] like to visit the countryside and seek for authentic events in which they will mingle with other locals and chat with people from the villages... They [referring to tourists] want a friendlier environment in which actual philoxenia is on offer ... [Sylvia, 33, rural community center-event organizer]

\section{Discussion}

The study findings support the argument that the concept of philoxenia differs from that of 'hospitality', the latter term being associated by respondents more with commercialized activities and rules. Interviewees did, however, note that expressions of philoxenia have altered over time, although the rural setting allows continuing opportunities for it to be offered. In more detail, the respondents in this study generally agreed that although the two terms philoxenia and hospitality are used interchangeably, they do differ. For instance, as one pointed out, philoxenia embraces strong emotions such as 'love', since it embraces the valuable word 'philos' (friend). In fact, through their responses, it seems that the offering of philoxenia is geared by love, which consecutively triggers a friendlier and more personal confrontation of the 'other'. That is, the guest is viewed more as a friend than as a customer, or even than as a guest. This dynamic process is illustrated in Figure 2.

Based on the responses of the interviewees, the notion of philoxenia also embraces qualities of 'hospitableness', such as benevolence (Lashley, 2015a). However, the traits of philoxenia seem to differ from such 'hospitableness' in certain ways. First, the review of the literature indicates that philoxenia is expressed through someone's active pursuit to offer it (Irekleous, 2015) without expecting anything in return. Secondly, philoxenia encompasses of a spiritual element (that is, philoxenia being linked with a spiritual conversation) and, third, based on the interviewees' responses, philoxenia (compared to hospitality) is perceived as more 'authentic' and 'genuine', reflected in 'love' expressions. In contrast, they regard the term 
Figure 2: The nexus of love and philoxenia

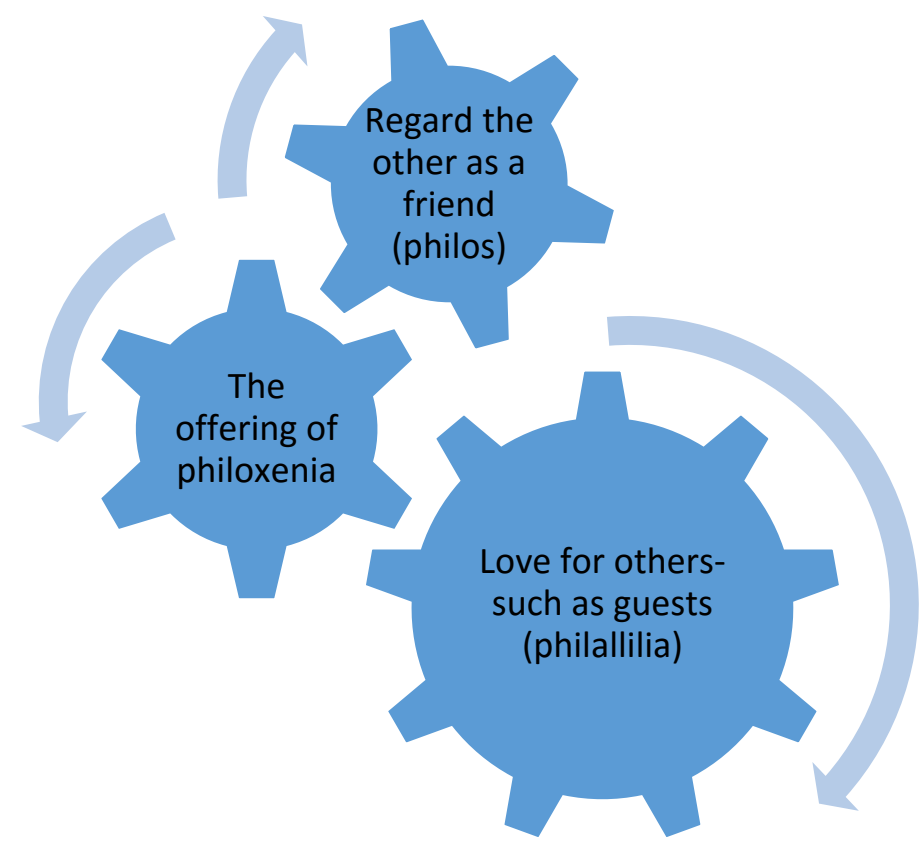

'hospitality' as rather 'shallow' since it is more linked to commercialized activities and standardized service procedures.

These distinguishing characteristics of philoxenia identified in the research enable the construction of a diagrammatic representation that summarizes the differences between philoxenia and hospitality. Specifically, Figure 3 below presents a grid matrix that includes the constructs the informants emphasized while describing the profound meanings of philoxenia compared to (commercialized) hospitality, these being 'authenticity/genuineness' (of hospitality providers' intentions/actions) and that of 'philoxenic' (friendship/love towards the other) attitudes in differing situations, such as in the case of rural tourism establishments.

In addition, interviewees referred to positive emotions and words such as love, empathy, understanding and warmth/comfort, revealing a psychological element attached to the notion of philoxenia. They also made more associations with the non-secular element, albeit without neglecting the physical/tangible element. According to some interviewees, philoxenia entails a secular dimension expressed through physical displays ('a genuine smile'), whilst another example would be the significance of a simplistic gesture, such as 'offering a cold beverage [to the guest] during a hot day' (Michael, 42, traditional restaurant owner). Furthermore, its core rests on 'love', which entails the actual aim of comforting someone, whether physically or psychologically (refer to the study of Christou, 2018, which discusses 
Figure 3: Philoxenia vs hospitality guided by commercial incentives

Perceived as less authentic

Because its influenced by commercial

rules, such as emotional labor

Philoxenia

(influenced by commercial rules, such as in certain

rural tourism

establishments)

Pro philoxenic attitude-

Guest regarded as a philos (friend) as a result of love towards the 'other'- guest

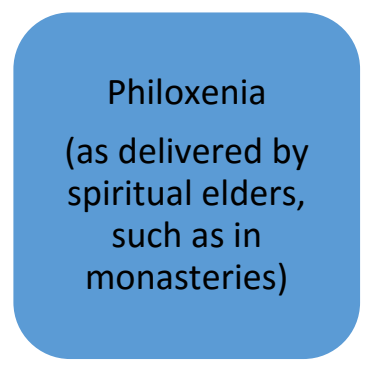

\section{Less philoxenic attitude-}

Guest regarded and treated more as a customer, than a 'philos'

Perceived as more authentic

Because it's not/or less-impacted

by commercial rules.

Hospitality, which the organizational culture cultivates a 'caring' culture towards guests

Figure 4: Deeper meanings of philoxenia

\section{The physical and tangible element}

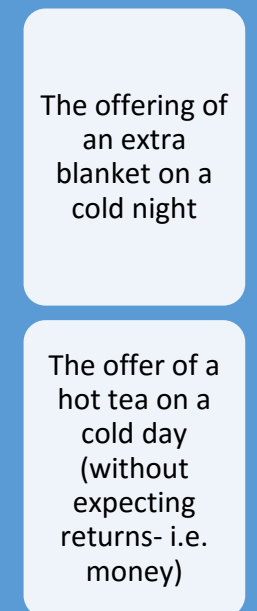

\section{The psychological/intangible} element

A genuine smile,

warmhearted gestures

Words of

kindness and empathy

\section{The 'love' element}

The pursue to comfort someone, by getting 'out of our comfort zone'
Psychological and spiritual support to a 'philos' 
the notion of agape). Hence, fieldwork enabled us to gain further insights to what philoxenia entails, as well as its deeper meanings. These are clarified in Figure 4.

Interviewees generally agreed that someone is ‘born' philoxenic. However, prior to any conclusions being made on whether this is the case, rigorous scientific evidence is required; this certainly opens up some potentially exciting avenues for further investigations of the concept, especially from a psychological perspective. Nevertheless, as respondents indicated, philoxenic attitudes may be further 'nurtured by family' while hospitable traits may also be learned and / or enhanced: '(a person) owes [themselves] to further develop'. All the same, philoxenia may be also cultivated within a person if philaftia is replaced with philallilia, since the egocentric stance of the former term leads to antithesis towards 'the other' (in Mantzarides, 2005a), as discussed below. With comments such as 'charisma', 'please the other' and 'unique element of our identity', the interview respondents seemed to regard a philoxenic attitude towards the receiver more as a pleasure and part of their inner identity rather than an 'obligation' (Lashley, 2008). However, the present study does not reveal whether hospitable attitudes are driven by potential 'have to' obligations to be polite or philoxenic with the expectation that the guest will 'repay' this kindness with, for example, a tip. Such seemingly 'hospitable actions' could conceivably be perceived by the receiver as superficial and fake, and so the guest may not benefit from genuine hospitality (Smith, 2009). Nevertheless, philoxenic people who embrace others wholeheartedly without expecting anything in return have been found to trigger intense positive emotions amongst their guests (Farasiotis, 2005).

Some respondents also linked philoxenia with the destination's identity, one example being Amelia (35, agritourism boutique hotel) who specifically referred to it as 'an integral part of the Cypriot culture'. This outcome contributes to the discourse of locals and sense of destination identity (Tinsley \& Lynch, 2008). More specifically, it adds to the discussion of locals' identity, pride and destination loyalty and preservation of such factors (in this case philoxenia) that encourage and support these. Locals are, thus, encouraged to embrace the ideals of philoxenia, such as giving and providing to others, without necessarily seeking a (monetary) return. Even so, it is arguable whether philoxenia should be offered or be fostered exclusively by a particular destination. Viewing hospitality as a welcome is significant (Lynch, 2017) while the need to welcome visitors is recognized and practiced around the globe (Blain \& Lashley, 2014). Some researchers have made reference to different societies and their hospitable obligations (Rosello, 2002; Shryock, 2004), whilst others have stressed the 
philoxenic attitudes demonstrated by people in other countries/regions (Mantzarides, 2005b). Hence, the offering of philoxenia is not restricted by regional boundaries, but is determined and established through human interfaces.

\section{Conclusion}

The purpose of this study was to explore whether philoxenia is still offered in an age when people may have no longer strong obligations to act hospitably. It was undertaken in response to calls for additional research (Cetin \& Okumus, 2018) and for further philosophical insights into the notion of hospitality, which is highly influenced by commercial domains. As Lashley (2017, p. 412) suggests, 'It is necessary to focus more on the development of (hospitality) graduates who are at least reflective, if not philosophical, practitioners'. The specific context of rural tourism was chosen to address the main aim of the study by targeting owners of small rural tourism accommodation and other establishments, such as taverns, in Cyprus. This is because rural tourism is characterized by idiosyncratic host-guest relationships, hospitable attitudes (Sharpley, 2002; Smith, 2009) and the emotional experiences (Sharpley \& Jepson, 2011) it entails. These allow for a more profound understanding of the notion of philoxenia and how it is currently manifested within a seemingly 'hospitable' context.

Of particular note is that none of the interviewees in the research used words that indicate or otherwise imply 'spiritual' offerings, despite the fact that philoxenia has been traditionally been associated both directly and indirectly (yet not necessarily) with spiritual conversations and advice (Speake \& Ware, 2015). Although this provides opportunities for further research, some justifications may be provided. For instance, this may conceivably be explained by tourists not being motivated to seek a countryside experience that essentially entails a spiritual element. Furthermore, it may be based on (rural tourism) stakeholders being unwilling or not interested in discussing such issues with their guests. Hence, it may be debatable whether philoxenia is actually offered by rural tourism providers if it is considered to entail a spiritual element or, indeed if it is presumed that it is governed by non-rational judgments (for example, giving without expecting something in return). That is, rural tourism providers may give priority to their financial survival despite them mentioning that a philoxenic person should not 'care about profit only'. However, from the results of this study, it is evident that philoxenia may be fostered and expressed in settings that support close human interactions, such as a small accommodation establishment in a village. Although the respondents shared a rather pessimistic view of a 'deteriorating' philoxenia in recent times, they nevertheless saw 
opportunities for the rural tourism sector. More specifically, they expressed the view that the countryside is an antidote for people seeking to escape from busy routines, 'feeling nostalgic' and longing for personal/social interactions, 'personal contact' and to 'mingle with the locals"' The rural tourism setting conceivably sets the basis for such philoxenic experiences since it provides opportunities for hosts to 'devote more time to our guests' and it is associated 'with personal communication' while family-run establishments 'make the ambiance friendlier'.

Nonetheless, the research also revealed that the offer of philoxenia faces a number of contemporary challenges. Specifically, the interviewees acknowledged a shift in values and priorities within the tourism sector, with people 'caring more about making a profit' and becoming 'rather selfish', 'demanding' and 'materialistic'. In fact, negative by valance internal attributes, such as profit-orientation and selfishness, as well as external impacts such as economic uncertainty and modernized procedures, appear to represent a significant challenge to hospitable attitudes. Other exogenous factors that may impact on the offering of philoxenia

Figure 5: Influences impeding, or encouraging the offering of philoxenia
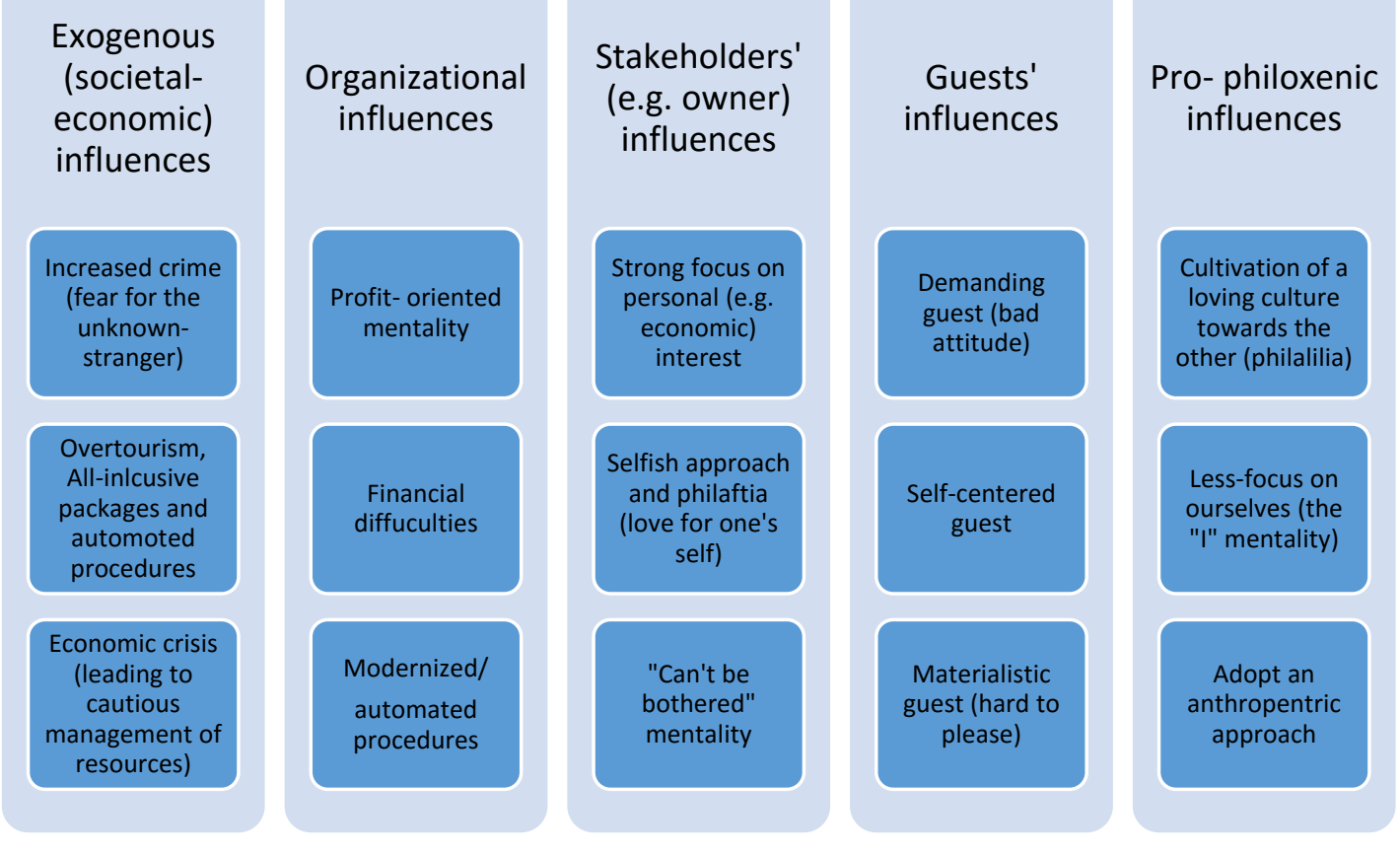

include the increased crime rates that lead to the fear of the unknown/stranger, whilst the economic challenges facing the owners of small tourism establishments may also impede their willingness to provide, for example, tangible items to guests in the spirit of philoxenia. 
Equally, it may be argued that a philoxenic person will not be diverted from a readiness to offer philoxenia to others, if taken that philoxenia is a 'charisma' that someone holds. Overall, however, the outcomes of this study enable the construction of a table that summarizes the various influences that may obstruct or enhance the offering of philoxenia (Figure 5).

Based on the above findings, this study yields certain managerial implications. First, the important role of service providers in shaping the hospitable experiences of guests (Cetin \& Okumus, 2018; Dekker, 2014; Telfer, 2013) is once more acknowledged and strengthened. In particular, the actions of rural tourism stakeholders should be driven and further strengthened by philoxenic attitudes based on the pivotal role of philoxenia within host-guest interactions. The importance of this kind of relationship is recognized both at a personal and social level (Causevic \& Lynch, 2009; Hemmington, 2007) whilst, as Suleri (2017, p.334) notes, 'we need a society where the stranger who is not even a member of the host's family still... enjoys the qualities of hospitableness'. Moreover, returning to some of the longhonoured fundamentals of the notion, hosts may follow examples of people who offer philoxenia by actively seek to offer it to their guests wholeheartedly, all without necessarily expecting returns, by developing their philalilia (love for the other), and putting aside philaftia (love for oneself). Although the particular rural setting may provide more opportunities for its offering as indicated by the responses of interviewees, philoxenia may also be offered by hospitality organizations more generally. This may be achieved by shifting organizational values from a 'commercial' to a more anthropocentric, and eventually 'philoxenic' orientation. By doing so, tourism organizations may benefit from being perceived as more anthropocentric rather than profit-centric, and as promoters of emotional rather than neutral experiences. Of course, this entails the full commitment of all stakeholders, including owners, managers and employees, and involves certain risks or challenges that the organization and people within would be called upon to address. These shifting values from core commercial into a more philoxenic-oriented culture, and the risks involved, are illustrated in Figure 6. Furthermore, it is important that 'philoxenic' attitudes are not solely channeled towards guests but also towards employees; that is, guests and management should not only be recipients of philoxenic attitudes, but also try to return them as a gesture of recognition and mutual respect.

This study has certain limitations. First, although qualitative studies do not rely on numbers to reach conclusions, it was not possible to identify differences emerging from differing ages and gender of informants. Second, no differences between private and public organizations' philoxenic offerings could be identified, although it may be argued that public organizations that are not governed by a commercial / profit imperative may be less reluctant 
Figure 6: Shifting values towards a philoxenic approach

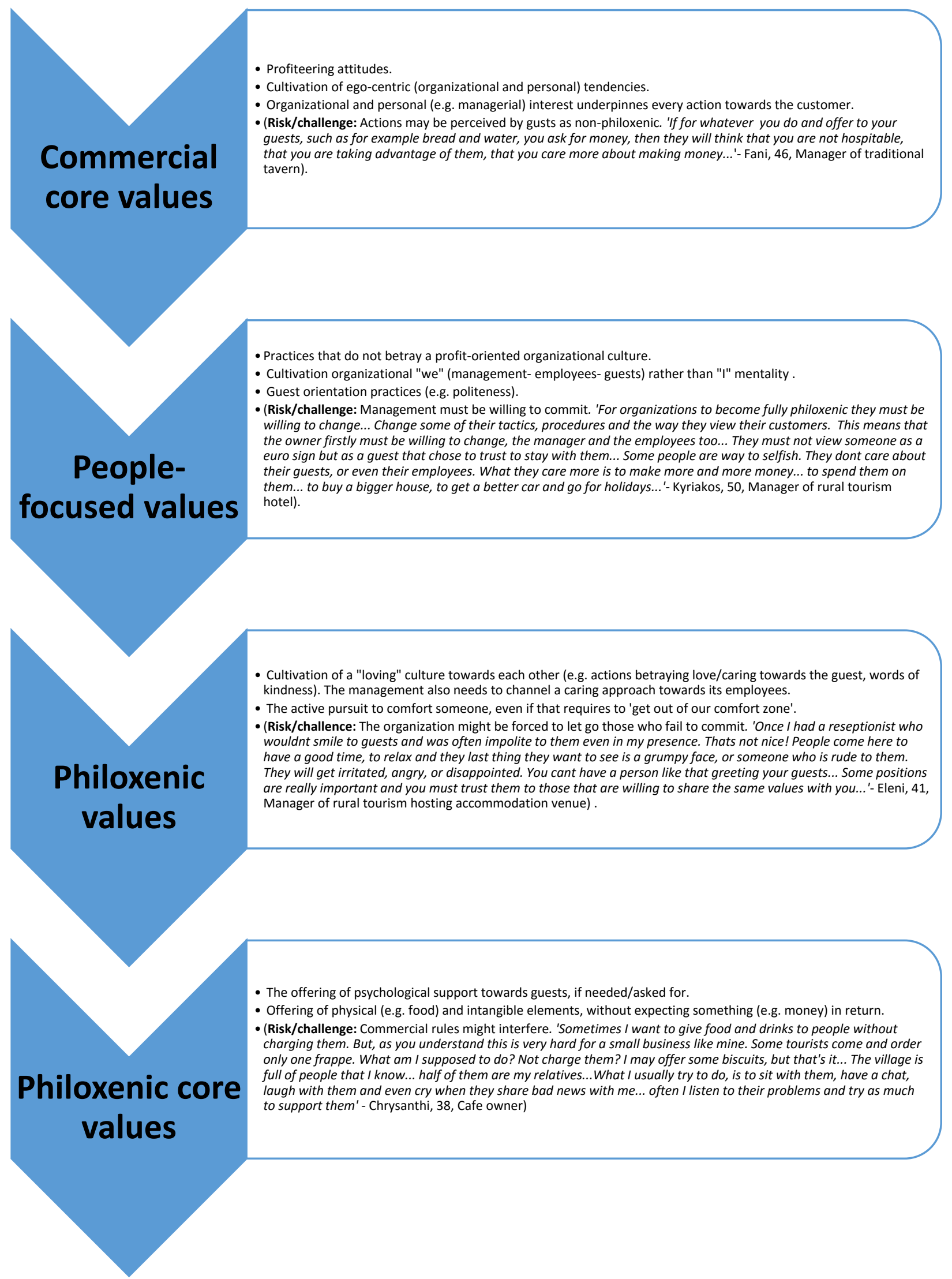


to offer philoxenia to their guests. Third, despite the fact that this study contributes significantly to the deeper meanings of philoxenia, it was not able to distinguish clearly the construct. This perhaps reflects the fact that the concept of philoxenia is inevitably impacted upon by commercial realities when considered within a commercial context, such as rural or other forms of tourism activity. Finally, the research did not reveal what precisely what is driving the claimed changes in tourists' behavior towards hosts' hospitality. That is, according to the respondents in this study, tourists have changed. Although some explanations were offered, it would be interesting to examine the deeper influences on tourists' attitudes and, also, the extent to which such attitudes shape the offering of philoxenia. In fact, based on this study, there are a number of further opportunities for research. Although the philosophical discussion of the general notion of hospitality is potentially limitless, a research agenda is presented below that may enable scholars to discover new knowledge. More specifically, further research could attempt to clarify why philoxenia is not found to involve a spiritual element. As mentioned, philoxenia has often been linked with the spiritual element, but the present study did not reveal any such associations. Prior conclusions are driven by whether the notion has been detached from such offerings. There is a need to explore the notion in settings which philoxenic core values may be still practiced, such as in monastic communities. Furthermore, according to the views of interviewees, philoxenia is an 'innate charisma', despite the fact that a person may learn to develop a philoxenic attitude by putting aside philaftia (love for one's self). Drawing on the interviewees' views, further research is suggested to scientifically explore this, with input from other fields, such as social psychology, likely to prove invaluable. Additionally, although the choice of setting and context for this study permitted a deeper understanding of the concept of philoxenia, future studies might involve different perspectives, such as those of guests and employees, in different settings to allow a more holistic appreciation of how contemporary hospitality is offered and consumed.

As a concluding statement, this study allowed an in-depth exploration of the construct of philoxenia from a philosophical, psycho-social and spiritual perspective within the context of rural tourism. Even so, based on the fieldwork, it cannot be simply concluded that philoxenia is offered for rural tourist consumption, as has been implied. Although there is evidence of philoxenic offerings by hosts, this study reveals that the potential for philoxenia is challenged by factors that impede its offering, such as the fear of the 'xenos' (stranger), a growing emphasis on core commercial practices and financial yield, a shift in values towards selfcenteredness, egoism tendencies, and philaftia. At the same time, however, the study has 
pointed to steps that tourism organizations may follow if they wish to develop a more anthropocentric culture which, in turn, may facilitate the delivery of strong emotional experiences to visitors, transforming them from guests into the sphere of 'philos', or friend.

\section{References}

Blain, M., \& Lashley, C. (2014). Hospitableness: The new service metaphor? Developing an instrument for measuring hosting. Research in Hospitality Management, 4 (1-2), 1-8.

Brotherton, B. (2015). Researching Hospitality and Tourism, $2^{\text {nd }}$ ed., Los Angeles; London; New Delhi; Singapore; Washington DC: Sage Publications.

Brotherton, B. (2005). The nature of hospitality: Customer perceptions and implications. Tourism and Hospitality Planning\& Development, 2 (3), 139-153.

Botherton, B. (1999). Towards a definitive view of the nature of hospitality and hospitality management. International Journal of Contemporary Hospitality Management, 11 (4), $165-173$

Brotherton, B. \& Wood, R.C. (2008). The nature and meanings of 'Hospitality'. In: Brotherton, B\& Wood, R.C. (Eds.) The Sage Handbook of Hospitality Management, Los Angeles; London; New Delhi; Singapore: Sage Publications.

Buda, D. \& McIntosh, A. (2013). Dark tourism and voyeurism: Tourist arrested for 'spying' in Iran. International Journal of Culture, Tourism and Hospitality Research, 7(3), 214216.

Cairns, S. (2007). Short Trip to the Edge. Where Earth Meets Heaven - A Pilgrimage. New York: Harper Collins.

Causevic, S. \& Lynch, P. (2009). Hospitality as a human phenomenon: Host-guest relationships in a post-conflict setting. Tourism and Hospitality Planning \& Development, 6(2), 121-132.

Cetin, G. \& Okumus, F. (2018). Experiencing local Turkish hospitality in Istanbul, Turkey. International Journal of Culture, Tourism and Hospitality Research, 12 (2), 223-237.

Choi, S. \& Fu, X. (2018). Hosting friends and family as a sojourner in a tourism destination. Tourism Management, 67, 47-58.

Choose your Cyprus. (2016). Available on: http://www.chooseyourcyprus.com/el/cyprusagrotourism.html. (Accessed: 15 January 2016). 
Christou, A. P. (2018). Exploring agape: Tourists on the island of love. Tourism Management, $68,13-22$.

Christou, P., Avloniti, A. \& Farmaki, A. (2018). Guests' perceptions of emotionally expressive and non-expressive service providers within the hospitality context. International Journal of Hospitality Management, corrected proof- article in press.

Christou, P., Lashley, C. \& Saveriades, A. (2009). The world of agritourists: A psychological perspective. Tourismos: An International Multidisciplinary Journal of Tourism, 4(4), 241-257.

Cooper C. \& Hall C.M. (2016). Contemporary Tourism: An International Approach, Oxford: Goodfellow Publishers

CYEU (2012). Filoxenia. Cyprus Presidency of the Council of the European Union. Available online at: $\quad$ http://www.cy2012.eu/el/menu/the-presidency-eu/cypruspresidency/filoxenia (Accessed 22 January 2016)

Dekker, D.M. (2014). Personality and hospitable behavior. In I. Pantelides, (Ed.). The Routledge Handbook of Hospitality Management, Abingdon: Routledge, pp. 57-66.

Derrida, J. (2002). Acts of Religion. London: Routledge.

Di Domenico, M. \& Lynch, P.A. (2007). Host/Guest encounters in the commercial home. Leisure Studies, 26(3), 321-338.

Farasiotis, D. (2005). The gurus, the young and Elder Paisios, $7^{\text {th }}$ ed. Thessaloniki.

Gehrels, S. (2017). Liquid hospitality: Wine as the metaphor. In C Lashley (Ed.), The Routledge Handbook of Hospitality Studies. Abingdon: Routledge, pp. 247- 259.

Germann Molz, J. \& Gibson, S. (Eds) (2007) Mobilizing Hospitality: The Ethics of Social Relations in a Mobile World. Aldershot: Ashgate.

Griffiths, I. \& Sharpley, R. (2012). Influences of nationalism on tourist-host relationships. Annals of Tourism Research, 39(4), 2051- 2072.

Griffin, T. (2013). Pilgrims and patriots: Australian tourist experiences in Gallipoli. International Journal of Culture, Tourism and Hospitality Research, 7(3), 227- 241.

Homer's Iliad (Z119-235). 2004- Zitros publications, ISBN: 9608437261

Hemmington, N. (2007). From service to experience: Understanding and defining the hospitality business. The Service Industries Journal, 27(6), 747-755.

Henn, M., Weinstein, M. \& Foard, N. (2006). A Short Introduction to Social Research. London: Sage.

Hennink, M., Hutter, I. \& Bailey, A. (2011). Qualitative Research Methods. Sage publications: London. 
Höckert, E. (2018). Negotiating Hospitality: Ethics of Tourism Development in the Nicaraguan Highlands, $1^{\text {st }}$ ed., Abingdon: Routledge.

Holloway, W., Jefferson, T. (2013). Doing Qualitative Research Differently: APpsychosocial approach, $2^{\text {nd }}$ ed., London: Sage Publications.

Irakleous, C. (2015). Paraklisi. Lemesos: Iera Mitropoli Lemesou, Cyprus

Isaak, (2004). Life of Elder Paisiou the Ayioritou. Ayion Oros.

Kolmogkorof, St Symeon. (1998). Elder Gabriel the Anchorite. Attica: Botsis.

Lashley, C. (2008). Marketing hospitality and tourism experiences. In H. Oh (Ed.), Handbook of Hospitality Marketing Management. Oxford: Butterworth- Heinemann, pp. 4-31.

Lashley, C. (2015a). Hospitality experience: An introduction to hospitality management. Journal of Tourism Futures, 1(2), 160-161.

Lashley, C. (2015b). Hospitality and hospitableness. Research in Hospitality Management, $5(1), 1-7$.

Lashley, C. (2017). Introduction: Research on hospitality. The story so far / ways of knowing. In C. Lashley (Ed.), The Routledge Handbook of Hospitality Studies. Abingdon: Routledge, 1-10.

Lekkou, E. (1992). Holy Married Couples in the Church's Life. Meta Paraklytikou Kanonos, Saitis publications.

Lugosi, P. (2017). Using abstract concepts in impact-focused organizational research: An empirical example deploying "hospitality". Qualitative Research in Organizations and Management: An International Journal, 12 (1), 18-34.

Lugosi, P. (2014). Hospitality and organizations: enchantment, entrenchment and reconfiguration. Hospitality and Society, 4 (1), 75-92.

Lyhnos (2016). Available online on: www.lyhnos.com. (Accessed 15 January 2016)

Lynch, A. P. (2017). Mundane welcome: Hospitality as life politics. Annals of Tourism Research, 64, 174-184.

Lynch, A. P. (2005). Sociological impressionism in a hospitality context. Annals of Tourism Research, 32 (3), 527-548.

Lynch, A. P. (2000). Networking in the homestay sector, Service Industries Journal, 20:3, 95116.

Lynch, A. P., Molz, J.G., Mcintosh, A., Lugosi, P. \& Lashley, C. (2011). Theorizing hospitality, Hospitality \& Society, 1 (1), pp. 3-24.

Mantzarides, G. I. (2005a). Social theory and act according to Great Basilios in Odoiporiko of Theological Anthropology. Holy Great Monastery of Vatopedi. 
Mantzarides, G. I. (2005b). Odoiporiko of Theological Anthropology. Holy Great Monastery of Vatopedi.

Mariampolski, H. (2006). Ethnography for marketers: A guide to consumer immersion, Thousand Oaks, Sage publications: CA.

Moore, L., Archimandrite. (2009). An extraordinary peace: St Seraphim, flame of Sarov. Anaphora Press.

O'Connor, D. (2005). Towards a new interpretation of 'hospitality'. International Journal of Contemporary Hospitality Management, 17(3), 267-271.

O'Gorman, K. D. (2007). The hospitality phenomenon: Philosophical enlightenment? International Journal of Culture, Tourism and Hospitality Research, 1(3), 189-202.

Orthodox Synaxaristis. (2015). Available online: www.saint.gr (site in Greek). Accessed: $06 / 2018$.

Paravouniotissa, I.N. (2011). $\quad H \quad \varphi l \lambda o \xi \varepsilon v i \alpha$ [Philoxenia]. Available online: http://www.paravouniotissa.gr/index.php/component/k2/item/214-\%CE\%B7\% $\mathrm{CF} \% 8 \% \mathrm{CE} \% \mathrm{~B} 9 \% \mathrm{CE} \% \mathrm{BB} \% \mathrm{CE} \% \mathrm{BF} \% \mathrm{CE} \% \mathrm{BE} \% \mathrm{CE} \% \mathrm{~B} 5 \% \mathrm{CE} \% \mathrm{BD} \% \mathrm{CE} \% \mathrm{AF} \%$ CE\%B1, Accessed: 05/2015; 05/2018.

Palinkas, L.A., Horwitz, S.M., Green, C.A., Wisdom, J.P., Duan, N. \& Hoagwood, K. (2015). Purposeful sampling for Qualitative data collection and analysis in mixed method implementation research. Administration and Policy in Mental Health and Mental Health Services Research, 42 (5), 533-544.

Patton, M. (2014). Qualitative Research and Evaluation methods, $4^{\text {th }}$ ed., London: Sage Publications.

Patton, M.Q. (2007). Sampling, qualitative (purposive). The Blackwell Encyclopedia of Sociology.

Paul, Apostle, A'. Epistle Paul towards Corinthians (1 $\left.\beta^{\prime} 27-1 \gamma^{\prime} 13\right)$ ).

Poulston, J. (2015). Expressive labour and the gift of hospitality, Hospitality \& Society, 5 (23), 145-165.

Ritchie, J. Lewis, J., Nicholls, C. \& Ormston, R. (2014). Qualitative Research Practice, $4^{\text {th }}$ ed., Sage: Los Angeles.

Ritzer, G. (2017). Hospitality and presumption. In C. Lashley (Ed.) The Routledge Handbook of Hospitality Studies. Abingdon: Routledge, pp. 233-246.

Rosello, M. (2002). Postcolonial Hospitality: The Immigrant as Guest. Stanford, California: Stanford University Press. 
Rosenbaum, M.S. (2009). Exploring commercial friendships from employees' perspectives. Journal of Services Marketing, 23 (1), 57-66.

Ruiter, V. (2017). Hunter and gatherer hospitality in Africa. In C. Lashley (Ed.), The Routledge Handbook of Hospitality Studies. Abingdon: Routledge, pp. 247- 259.

Scokic, V., Lynch, P. \& Morrison, A. (2016). Hotel entrepreneurship in a turbulent environment, International Journal of Hospitality Management, 53, 1-11.

Severt, D., Aiello, T., Elswick, S. \& Cyr, C. (2008) Hospitality in hospitals? International Journal of Contemporary Hospitality Management, 20(6), 664-678.

Sharpley, R. (2002). Rural tourism and the challenge of tourism diversification: The case of Cyprus. Tourism Management, 23(3), 233-244.

Sharpley, R. (2014). Host perceptions of tourism: A review of the research. Tourism Management, 42(1), 37-49.

Sharpley, R. \& Jepson, D. (2011). Rural tourism: a spiritual experience? Annals of Tourism Research, 38(1), 52-71.

Sharpley, R., \& Stone, P. (Eds.). (2014). Contemporary tourist experience: Concepts and consequences (Vol. 27). Routledge.

Shryock, A. (2004). The new Jordanian hospitality: House, host and guest in the culture of public display. Comparative Studies in Society and History, 46(1) 35-62.

Skandrani, H. \& Kamoun, M. (2014). Hospitality meanings and consequences among hotels employees and guests. In A. Woodside and M. Kozak (Eds). Tourists' Perceptions and Assessments (Advances in Culture, Tourism and Hospitality Research, Volume 8). Bradford: Emerald, pp.147 - 156

Slattery, P. (2002). Finding the hospitality industry. Journal of Hospitality, Leisure Sport and Tourism, 1(1), 19-28.

Smith, M. K. (2009). Issues in Cultural Tourism Studies, $2^{\text {nd }}$ Edition. Abingdon: Routledge.

Speake, G. (2005). Mount Athos: Renewal in Paradise. New Haven and London: Yale University Press.

Speake, G. \& Ware, K. (2015). Spiritual Guidance on Mount Athos. Bern: International Academic Publishers.

Suleri, J. (2017). Experiencing hospitality and hospitableness. In C. Lasley (Ed.), The Routledge Handbook of Hospitality Studies. Abingdon: Routledge, 326- 336.

Suri, H. (2011). Purposeful sampling in qualitative research synthesis. Qualitative Research Journal, 11 (2), 63-75. 
Sweeney, M., Hughes, J.D. \& Lynch, P. (2018). Lifestyling entrepreneurs' sociological expressionism. Annals of Tourism Research, 69, 90-100.

Tasci, A. \& Semrad, K. (2016). Developing a scale of hospitableness: A tale of two worlds. International Journal of Hospitality Management, 53, 30-41.

Telfer, E. (2013). The philosophy of hospitableness. In: C. Lashley and A. Morrison, (Eds), In Search of Hospitality: Theoretical Perspectives and Debates. Oxford: ButterworthHeinemann, pp. 255-275.

The Buonvicino Rural Tourism. (2015). Available online on: https://www.airbnb.gr/rooms/1120074. (Accessed 01/2016)

Thomas, D.R. (2006). A general Inductive Approach for analyzing qualitative evaluation data. American Journal of Evaluation, 27 (2), 237- 246.

Tinsley, R. \& Lynch, P.A. (2008). Differentiation and tourism destination development: Small business success in a close-knit community. Tourism and Hospitality Research, 8 (3), 161-177.

Tongco, M. (2007). Purposive sampling as a tool for informant selection. Ethnobotany Research \& Applications, 5, 147- 158.

Tucker, H. \& Lynch, P. (2005). Host-guest dating: The potential of improving the customer experienced through host-guest psychographic matching. Journal of Quality Assurance in Hospitality \& Tourism, 5 (2-4), 11-32

Tussyadiah, I.P. \& Park, S. (2018). When guests trust hosts for their words: Host description and trust in sharing economy. Tourism Management, 67, 261-272.

Zarkia, C. (1996). Philoxenia: Receiving tourists- but not guests- on a Greek island. In: Boissevain, J. (Ed.). Coping with Tourists: European Reactions to Mass Tourism, Providence, Oxford: Berghahn Books. 